\title{
Antitumor effect of sunitinib in human prostate cancer cells functions via autophagy
}

\author{
BANGQI WANG ${ }^{1,2^{*}}$, DONGYUAN LU ${ }^{3 *}$, MIN XUAN $^{4 *}$ and WEILIE HU ${ }^{2}$ \\ ${ }^{1}$ Southern Medical University, Guangzhou, Guangdong 510515; ${ }^{2}$ Department of Urology, \\ General Hospital of Guangzhou Military Command, Guangzhou, Guangdong 510010; \\ ${ }^{3}$ Graduate School of The Second Military Medical University, Shanghai 200433; ${ }^{4}$ Department of Plastic Surgery, \\ General Hospital of Guangzhou Military Command, Guangzhou, Guangdong 510010, P.R. China
}

Received October 25, 2015; Accepted November 25, 2016

DOI: $10.3892 /$ etm.2017.4134

\begin{abstract}
The aim of the present study was to explore sunitinib-induced autophagic effects and the specific molecular mechanisms involved, in vitro, using PC-3 and LNCaP human prostate cancer cell lines. Cells were exposed to escalating doses of sunitinib treatment and subsequent cell viability and cell cycle analyses were performed to evaluate the inhibitory effect of sunitinib in vitro. Immunofluorescence staining of microtubule associated protein 1A/1B-light chain 3 (LC3) puncta was employed to assess autophagy levels after sunitinib treatment. Western blot analysis was performed to evaluate variations in the levels of LC3, sequestosome-1, extracellular signal regulated kinase 1/2 (ERK1/2), mammalian target of rapamycin (mTOR), p70 ribosomal protein S6 kinase (p70S6K) and cleaved caspase-3 proteins. The present study revealed that sunitinib treatment inhibited cell growth and triggered autophagy in a dose-dependent manner in both cell lines. In addition, sunitinib activated ERK1/2 and inhibited mTOR/p70S6K signaling. Sunitinib-induced autophagy was notably reversed by ERK1/2 kinase inhibitor, U0126. Furthermore, inhibition of sunitinib-induced autophagy by 3-methyladenine enhanced apoptosis and exhibited improved cell viability, which indicated that sunitinib induces not only apoptosis but also autophagic cell death in prostate cancer cell lines. These results may lead to an improved understanding of the mechanism of sunitinib's cytotoxic action and may provide evidence that combined sunitinib autophagy-regulating treatment may be of benefit to anti-prostate cancer therapy.
\end{abstract}

Correspondence to: Dr Weilie Hu, Department of Urology, General Hospital of Guangzhou Military Command, 111 Liuhua Road, Guangzhou, Guangdong 510010, P.R. China

E-mail: huwl-mr@vip.sina.com

*Contributed equally

Key words: sunitinib, autophagy, apoptosis, prostate cancer cells, extracellular signal-regulated kinases $1 / 2$, mechanistic target of rapamycin

\section{Introduction}

Prostate cancer (PCa) is the most common type of malignant tumor among men and the annual rate of $\mathrm{PCa}$-related mortality is increasing rapidly worldwide (1). Treatments for prostate cancer include active surveillance, surgery, radiation therapy, chemotherapy, hormonal therapy, high-intensity focused ultrasound, or various combinations of these strategies. However, therapies for treating advanced $\mathrm{PCa}$ are considered to be largely ineffective $(2,3)$.

Autophagy is an important homeostatic cellular recycling mechanism responsible for degrading unnecessary or dysfunctional cellular organelles and proteins in all living cells (4). Autophagy promotes a cell survival response and may be triggered by distinct cellular stress, including nutrient starvation, pathogen-associated molecular patterns and virus infection $(5,6)$. Cells that undergo excessive autophagy may undergo cell death in a non-apoptotic manner (7). Additionally, the mammalian target of rapamycin (mTOR) signaling pathways have been reported to be involved in autophagy regulation in mammalian cells $(8,9)$. Activation of extracellular signal-regulated kinases $1 / 2$ (ERK1/2) has also been reported to be associated with autophagic regulation (10).

Sunitinib, which is a multi-targeted receptor tyrosine kinase (RTK) inhibitor, is approved for the treatment of advanced kidney cancer, imatinib-resistant gastrointestinal stromal cancer, pancreas adenocarcinoma and other types of solid-organ cancer (11-15). This anti-cancer agent has been described as an efficient therapeutic tool due to its desirable features in targeting apoptosis and oxidative stress $(16,17)$. In $\mathrm{PCa}$, preclinical and clinical studies have shown that sunitinib is able to inhibit $\mathrm{PCa}$ angiogenesis and proliferation, inducing prostate carcinoma cell apoptosis $(18,19)$. However, while it may be possible that sunitinib may induce autophagy in $\mathrm{PCa}$, the underlying effect and mechanism of autophagy in $\mathrm{PCa}$ remains unclear.

In the present study, the cytotoxicity and autophagy induced by sunitinib were explored using PC-3 and $\mathrm{LNCaP}$ human $\mathrm{PCa}$ cell lines. The effects of sunitinib on cell proliferation, cell cycle, autophagy and apoptotic cell death were investigated in PC-3 and LNCaP cell lines. Furthermore, the mechanisms 
of sunitinib-induced cell death were examined, specifically ERK1/2 phosphorylation and mTOR signaling.

\section{Materials and methods}

Cell culture and materials. PC-3 and LNCaP human PCa cell lines were obtained from the American Type Culture Collection (Manassas, VA, USA). Cells were maintained in a 1:1 mixture of Dulbecco's modified Eagle's medium (DMEM), Ham's F-12 nutrient mixture (HyClone; GE Healthcare Life Sciences, Logan, UT, USA) and RPMI 1640 medium supplemented with $10 \%$ fetal bovine serum (FBS) (both HyClone; GE Healthcare Life Sciences), respectively. Sunitinib malate powder was supplied by Pfizer, Inc., (New York, NY, USA); 3-methyladenine (3-MA) and U1260 ERK inhibitor were purchased from Sigma-Aldrich (Merck Millipore, Darmstadt, Germany). All reagents were diluted in dimethyl sulfoxide (DMSO) and stored at $-20^{\circ} \mathrm{C}$.

Cell viability assay. Cell viability assays following sunitinib treatment were performed using a cell counting kit-8 (CCK-8; Dojindo Molecular Technologies, Inc., Kumamoto, Japan). PC-3 and LNCaP cells were seeded in 96-well plates $\left(1 \times 10^{4}\right.$ cells/well) with culture medium supplemented with $10 \% \mathrm{FBS}$ and were incubated at $37^{\circ} \mathrm{C}$ in incubator with an atmosphere of $5 \% \mathrm{CO}_{2}$ for $12 \mathrm{~h}$ to allow adherence. Cells were treated with $10 \mu 1$ culture medium containing $0,5,10$ or $20 \mu \mathrm{mol} / \mathrm{l}$ of sunitinib for $24 \mathrm{~h}$. A total of $10 \mu \mathrm{l} \mathrm{CCK}-8$ was added to the cells, following sunitinib treatment, and the cells were incubated for a further $2 \mathrm{~h}$ at $37^{\circ} \mathrm{C}$. A microplate reader was used to measure the absorbance of each well at $450 \mathrm{~nm}$, and inhibition rates were calculated as follows: Viability rate $(\%)=\left\{\left[\mathrm{A}_{450}(\right.\right.$ sample $)-\mathrm{A}_{450}($ blank $\left.)\right] /$ $\left[\mathrm{A}_{450}\right.$ (control)- $\mathrm{A}_{450}$ (blank)]\}x100.

Cell cycle analysis. Cell cycle distribution was conducted by staining DNA with propidium iodide (PI; Sigma-Aldrich, Merck Millipore). Cells were trypsinized, fixed overnight in $70 \%$ ice-cold ethanol, washed twice with PBS, then centrifuged at $223.6 \times \mathrm{g}$. Cells were incubated with RNase (50 $\mu \mathrm{l}$ at $100 \mu \mathrm{g} / \mathrm{ml}$ ) for $10 \mathrm{~min}$, stained with propidium iodide (200 $\mu \mathrm{l}$ at $50 \mu \mathrm{g} / \mathrm{ml}$; cat. no. 81845; Sigma-Aldrich) for $1 \mathrm{~h}$ at room temperature. The percentage of cells in the different phases of the cell cycle were then analyzed with the FACSAria II flow cytometer using CellQuest7.6.2 software (both BD Biosciences, San Jose, CA, USA). ModFit v. 3.3.11 (Verity Software House, Topsham ME, USA) was used for data analysis.

Apoptosis assays. Apoptosis was determined by Annexin V-PE vs. 7-amino-actinomycin D (7-AAD) staining, using a PE Annexin V Apoptosis Detection kit I (BD Biosciences), according to the manufacturer's instructions. Cells were analyzed using a FACSCalibur flow cytometer and CELLQuest software (BD Biosciences).

Immunofluorescence staining. Cells were seeded on sterile cover slips in 6-well tissue culture plates at a concentration of $1 \times 10^{5} \mathrm{cell} / \mathrm{ml}$ in a volume of $0.6 \mathrm{ml}$. Following treatment with either DMSO (control) or sunitinib $(5,10$ or $20 \mu \mathrm{mol} / \mathrm{l})$ for
$24 \mathrm{~h}$, cells were fixed onto slides with $4 \%$ (v/v) paraformaldehyde for $20 \mathrm{~min}$, blocked with $5 \%$ bovine serum albumin for $30 \mathrm{~min}$ at room temperature and incubated with microtubule associated protein 1A/1B-light chain 3 (LC3) antibody (cat. no. sc292354; Santa Cruz Biotechnology, Inc., Dallas, TX, USA; dilution 1:200) overnight at $4^{\circ} \mathrm{C}$. Subsequently, the treated cells were washed three times with PBS and incubated at room temperature with AlexaFluor 488-conjugated anti-rabbit secondary antibody (cat. no. A-11008; Thermo Fisher Scientific, Inc., Waltham, MA, USA; dilution 1:1,000) for $1 \mathrm{~h}$. Fluorescence was measured using a confocal microscope (Leica Microsystems, Inc., Buffalo Grove, IL, USA; x630 magnification). Quantitation of the LC3 puncta was performed by counting 10 cells manually for each sample.

Western blot analysis. Cells were washed twice with ice-cold PBS and lysed in lysis buffer (1\% NP-40, $5 \mathrm{mM} \mathrm{NaPPi}, 150 \mathrm{mM}$ $\mathrm{NaCl}, 20 \mathrm{mM}$ Tris HCL (pH 7.5), $5 \mathrm{mM} \mathrm{Na}_{3} \mathrm{VO} 4,1 \mathrm{mM}$ PMSF and $10 \mu \mathrm{g} / \mathrm{ml}$ leupeptin). Samples were vortexed briefly, incubated in lysis buffer for $30 \mathrm{~min}$ on ice and centrifuged at $15,000 \times \mathrm{g}$ for $15 \mathrm{~min}$. Protein concentration was determined by the Bradford method. Equal amounts of samples containing total protein $(20 \mu \mathrm{g})$ were separated using 10-15\% SDS-PAGE and transferred onto polyvinylidene fluoride membranes (cat. no. IPVH00010; Merck KGaA, Darmstadt, Germany). Membranes were blocked in 5\% non-fat milk for $1 \mathrm{~h}$ at room temperature, incubated with the below indicated primary antibodies in nonfat milk overnight at $4{ }^{\circ} \mathrm{C}$, then washed with PBS $/ 0.1 \%$ Tween 20 for $1 \mathrm{~h}$. Membranes were then incubated with horseradish peroxidase-conjugated goat anti-rabbit IgG (cat.no. 111-035-003; Jackson Immunoresearch Labs, Inc., West Grove, PA, USA; dilution, 1:20,000) or rabbit goat anti-mouse IgG (cat. no. 115-035-003; Jackson Immunoresearch Labs, Inc.; dilution 1:20,000) for $1 \mathrm{~h}$. Subsequently, membranes were washed with PBS $/ 0.1 \%$ Tween-20 for 40 min and detected with enhanced chemiluminescence. Primary antibodies used in western blotting, according to the manufacturer's instructions, were: Anti-LC3, anti-sequestosome-1 (SQSTM1/p62), anti-mTOR, anti-p-mTOR (Ser2481), anti-p-p70S6K (Thr389) (Cell Signaling Technology, Inc., Danvers, MA, USA), $\beta$-actin, anti-p-ERK1/2 (Thr202/Tyr204), anti-ERK1/2 (Santa Cruz Biotechnology) and anti-cleaved-caspase3 (Beyotime Institute of Biotechnology, Jiangsu, China). Bands were revealed using an enhanced chemiluminescence reagent (ECL) in an ECL Plus kit (Beyotime Institute of Biotechnology, Jiangsu, China) and recorded on X-ray films (Fujifilm Life Science, Tokyo, Japan).

MTT assay. Cell viability was measured by the 3-(4,5-dimethylthiazol-2-yl)-2,5-diphenyltetrazolium bromide (MTT) assay (cat. no. 11465007001; Roche Diagnostics, Basel, Switzerland). Cells were plated at 5,000 cells/well in 96-well plates, in triplicate. Cells were allowed to adhere overnight, and medium containing the test drug or control media was added. After incubation for $48 \mathrm{~h}$ at $37^{\circ} \mathrm{C}$ in $5 \% \mathrm{CO}_{2}$, the drug-containing medium was removed and replaced by $100 \mu 1$ fresh medium with $0.5 \mathrm{mg} / \mathrm{ml}$ MTT solution. After incubation for $4 \mathrm{~h}$, the medium with MTT was removed and $100 \mu \mathrm{l}$ solubilization solution was added to each well. The plates were then gently agitated until the color reaction 
A

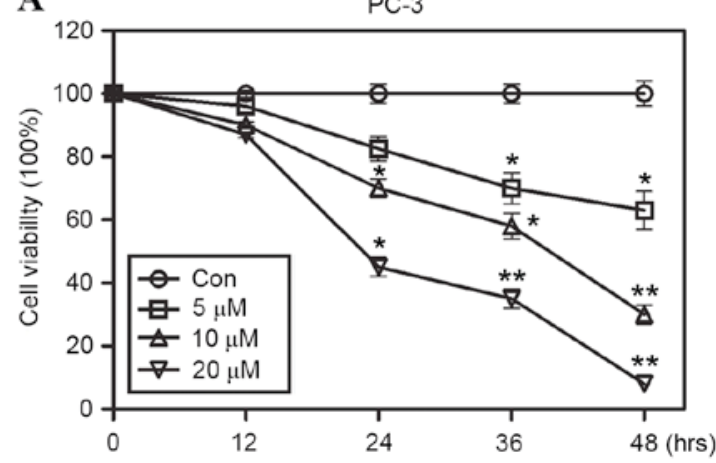

B

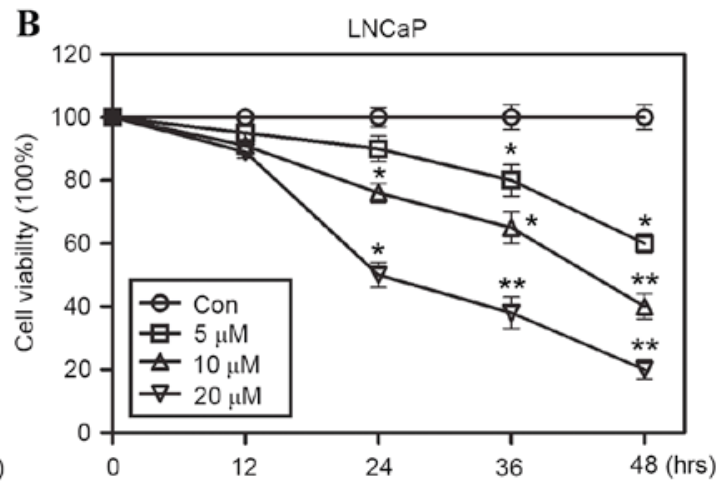

Figure 1. Effect of sunitinib on the proliferation in PC-3 and LNCaP cells. Following 5, 10 or $20 \mu$ mol/1 sunitinib treatment in PC-3 and LNCaP cells for 24 h, cell viability was measured using a Cell Counting Kit-8 kit assay. Sunitinib inhibited the proliferation of (A) PC-3 and (B) LNCaP cells in a dose-dependent manner. Data are presented as mean \pm standard deviation $(n=4)$. ${ }^{*} \mathrm{P}<0.05$ and ${ }^{* *} \mathrm{P}<0.01$ vs. Con. Con, control.

was uniform, and the $\mathrm{OD}_{570}$ (optical density at a wavelength of $570 \mathrm{~nm}$ ) was determined using a microplate reader (Wellscan MK3, Labsystems Diagnostics, Vantaa, Finland). Media-only treated cells served as the indicator of $100 \%$ cell viability. Viability rate $(\%)=\left\{\left[\mathrm{A}_{570}(\right.\right.$ sample $)-\mathrm{A}_{570}$ (blank) $] /$ $\left[\mathrm{A}_{570}\right.$ (control)- $\mathrm{A}_{570}$ (blank)]\}x100.

Statistical analysis. All results presented were confirmed in at least three independent experiments. Data were presented as mean \pm standard deviation. Statistical analysis was performed using one-way analysis of variance with Bonferroni's post-hoc tests for multiple comparisons. $\mathrm{P}<0.05$ was considered to indicate a statistically significant difference.

\section{Results}

Sunitinib inhibits the growth of PC-3 and LNCaP cells in vitro. To ascertain the inhibitory effect of sunitinib on the growth of PCa cells, cell viability assays were performed using PC-3 and LNCaP cells, either in the presence of sunitinib at different concentrations $(5,10$ or $20 \mu \mathrm{mol} / \mathrm{l})$ or in the absence of sunitinib and treated instead with DMSO (control) for $24 \mathrm{~h}$. Significant inhibitory effects on cell growth in PC-3 and LNCaP cells were observed in a dose-dependent manner (Fig. 1A and B, respectively), which may suggest that sunitinib possesses a potent cytotoxic activity against both human PCa cell lines.

Sunitinib induces G1-phase arrest in PC-3 and LNCaP cells. Cell viability assays revealed that sunitinib treatment significantly inhibited the proliferation of PC-3 and LNCaP cells. Subsequently, whether the inhibition effect on cell proliferation was related to cell cycle progression was detected. Flow cytometric analysis indicated that $10 \mu \mathrm{M}$ sunitinib treatment for $48 \mathrm{~h}$ resulted in the accumulation of cells in the $\mathrm{G} 1$ phase in PC-3 cells, $(76.36 \pm 4.78 \%)$ compared with the control $(51.82 \pm 7.02 \%)$, and in LNCaP cells $(65.83 \pm 7.99 \%)$ compared with the control $(53.32 \pm 6.08 \%)$ (Fig. 2). Furthermore, the populations of PC-3 and LNCaP cells in G2/M phase decreased significantly $(\mathrm{P}=0.037$ and 0.032 for $\mathrm{PC}-3$ and $\mathrm{LNCaP}$, respectively), from $19.42 \pm 2.49 \%$ and $20.65 \pm 1.85 \%$ in the control groups to $(8.58 \pm 1.03 \%)$ and $(12.11 \pm 1.17 \%)$ after sunitinib treatment (Fig. 2). These results indicated that sunitinib induced G1-phase arrest in PC-3 and LNCaP cells.
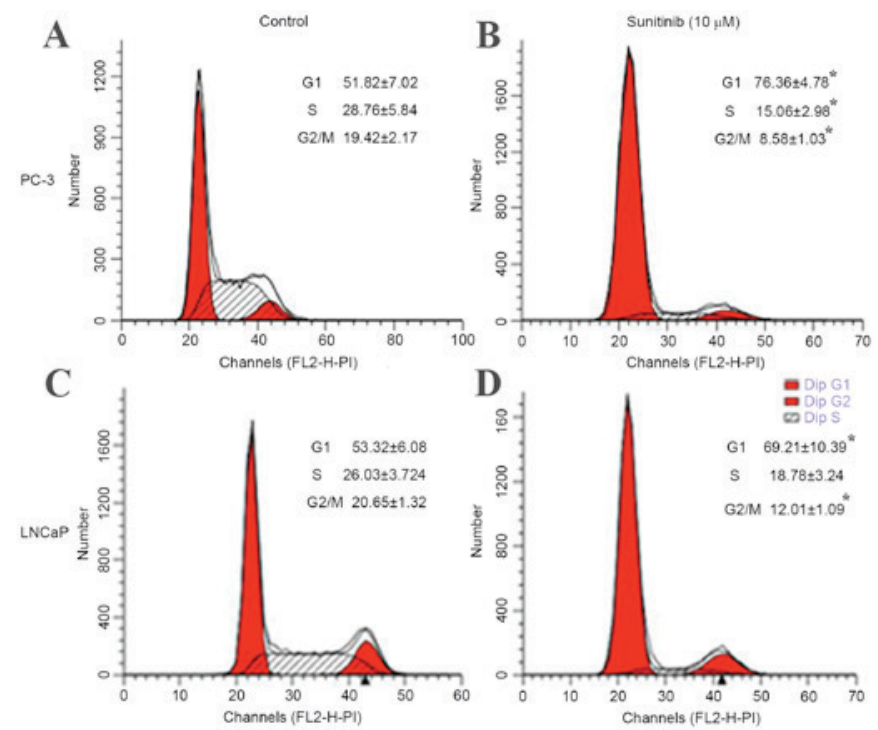

Figure 2. Cell-cycle (G0/G1, S and G2/M) analysis of PC-3 and LNCaP cells exposed to sunitinib $(10 \mu \mathrm{M})$ or DSMO (control) for $48 \mathrm{~h}$. Flow cytometric analysis was performed using PC-3 and LNCaP human PCa cells to establish the percentage of cells in G0/G1, S and G2/M phases of the cell cycle. (A) Control PC-3 cells treated with DSMO. (B) PC-3 cells treated with $10 \mu \mathrm{M}$ sunitinib. (C) Control LNCaP cells treated with DSMO. (D) LNCaP cells treated with $10 \mu \mathrm{M}$ sunitinib. Data are presented as mean \pm standard deviation $(n=4) .{ }^{*} \mathrm{P}<0.05$ vs. control. DSMO, dimethyl sulfoxide.

Sunitinib induces autophagy in PCa cell lines. Sunitinib, which is a multi-targeted tyrosine kinase inhibitor, exhibits anti-angiogenic and anti-tumor activity and has been approved by a large body of research $(20,21)$. It was speculated that sunitinib may also induce autophagy in PCa cells. Western blot analysis of SQSTM1/p62 and LC3 and subsequent immunofluorescence staining of LC3 puncta was performed to evaluate autophagy. PC-3 and LNCaP cells were treated for $24 \mathrm{~h}$ with various concentrations $(5,10$ or $20 \mu \mathrm{mol} / \mathrm{l})$ of sunitinib or DMSO (control), respectively. Cells were subjected to immunofluorescence staining and dose-dependent formation of LC3 fluorescence dots was observed. Limited numbers of LC3 punctas were observed in control groups (DMSO) in both cell lines. However, following sunitinib treatment, the LC3 puncta numbers increased significantly (when comparing the 5,10 or $20 \mu \mathrm{mol} / 1$ groups with the control, $\mathrm{P}<0.001$ for 
A
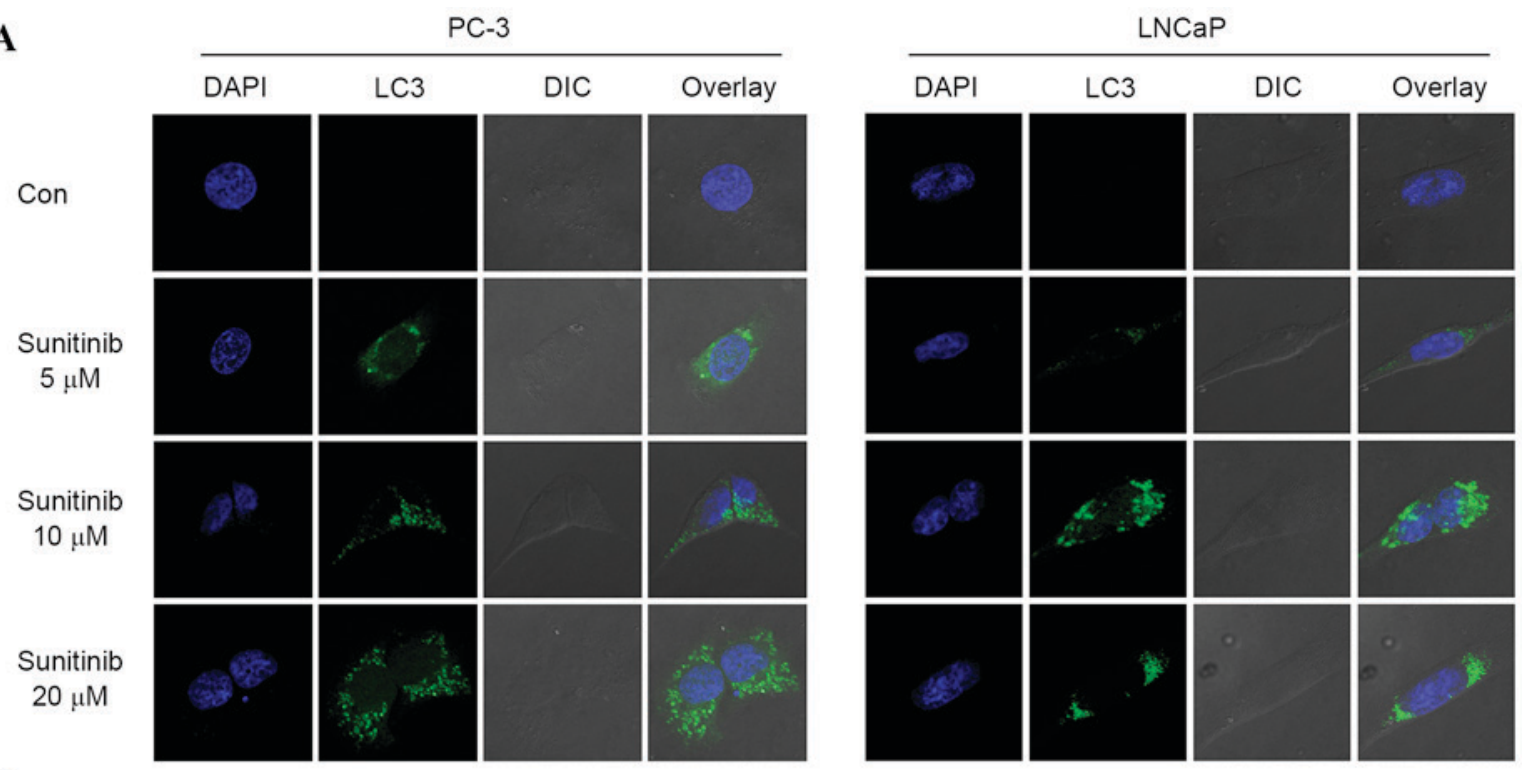

B
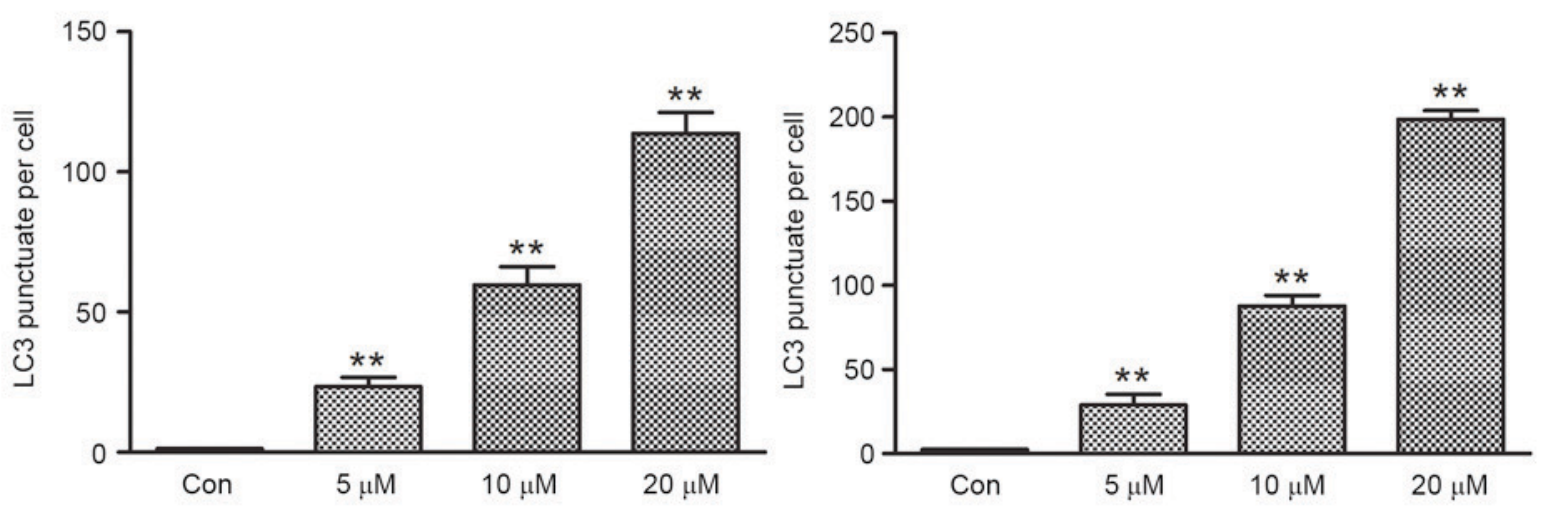

Figure 3. Effect of sunitinib on the formation of LC3 puncta in PC-3 and LNCaP cells. (A) Fluorescence images obtained from sunitinib-treated and control groups of prostate cancer cells, PC-3 and LNCaP. Cells treated with DMSO were set as control groups, the numbers of LC3 puncta per cell were counted manually. The number of LC3 puncta (green fluorescent) per cell in sunitinib-treated groups increased in a dose dependent manner (magnification, x630). (B) Limited numbers of punctas were located in control group PC-3 and LNCaP cells. The numbers of LC3 puncta per cell in PC-3 cells of 5,10 and $20 \mu \mathrm{M}$ sunitinib-treated groups were $23.29 \pm 3.36,59.74 \pm 6.48$ and $113.71 \pm 7.52$, respectively. The numbers of LC3 puncta per cell in LNCaP cells of 5, 10 and $20 \mu \mathrm{M}$ sunitinib-treated groups were $28.90 \pm 6.34,87.56 \pm 6.45$ and $198.56 \pm 5.33$, respectively. Data are presented as means \pm standard deviation $(\mathrm{n}=4)$. ${ }^{*} \mathrm{P}<0.05$ and ${ }^{* *} \mathrm{P}<0.01$, vs. Con. DSMO, dimethyl sulfoxide. LC3, microtubule associated protein 1A/1B-light chain 3; Con, control; DAPI, 4',6-diamidino-2-phenylindole; DIC, differential interference contrast.

PC-3, and $\mathrm{P}<0.002$ for $\mathrm{LNCaP})$, corresponding with increasing concentrations of sunitinib (Fig. 3A and B).

A hallmark of autophagy is the enhanced conversion of microtubule-associated protein 1 light chain 3 (LC3-I) to its faster-migrating form LC3-II, which is closely associated with the membrane of autophagosomes. Degradation of SQSTM1/p62 is used as a marker of autophagic flux (22). p62 is incorporated into autophagosomes and degraded in autolysosomes. Compared with the control groups, significantly increased expression levels of LC3-II (when comparing the 5,10 and $20 \mu \mathrm{mol} / 1$ groups with the control, $\mathrm{P}=0.017,<0.001$ and $<0.001$ for $\mathrm{PC}-3$, and $\mathrm{P}=0.028,<0.001$ and $<0.001$ for LNCaP, respectively), accompanied by decreased expression levels of SQSTM1/p62, were observed in dose-dependent manners in PC-3 and LNCaP cells exposed to sunitinib for $24 \mathrm{~h}$ (Fig. 4A-C). These findings indicated that sunitinib may have induced autophagy in the human PCa cell lines. contributes to sunitinib-induced autophagy in PC-3 and
LNCaP cells. Previous studies have confirmed that activation of AKT/mTOR pathway negatively regulates autophagy $(23,24)$. In order to assay the direct effect of sunitinib on the activation or inhibition of ERK and mTOR signaling, western blot analysis was performed to explore the role of specific components involved in autophagy flux regulation by observing the expression levels of total ERK1/2, mTOR, phosphorylated ERK1/2, mTOR and p70S6K. Treatment with sunitinib at different concentrations for $24 \mathrm{~h}$ induced a significant upregulation of phosphorylated ERK1/2 (when comparing the 5, 10 or $20 \mu \mathrm{mol} / \mathrm{l}$ groups with the control, $\mathrm{P}=0.050,0.003$ and $<0.001$ for PC-3, and P=0.044, 0.048 and $<0.001$ for LNCaP, respectively) in a dose-dependent manner for both $\mathrm{PCa}$ cell lines (Fig. 5). Furthermore, the expression levels of mTOR and its substrate, p70S6K, and their phosphorylated forms, were investigated to reveal whether the mTOR pathway may be responsible for sunitinib-induced autophagy. The results revealed that 10 and $20 \mu \mathrm{mol} / 1$ sunitinib treatment significantly inhibited the phosphorylation of mTOR $(\mathrm{P}=0.008$ and 0.002 for PC-3, and $\mathrm{P}=0.005$ and 0.001 for $\mathrm{LNCaP}$, 
A

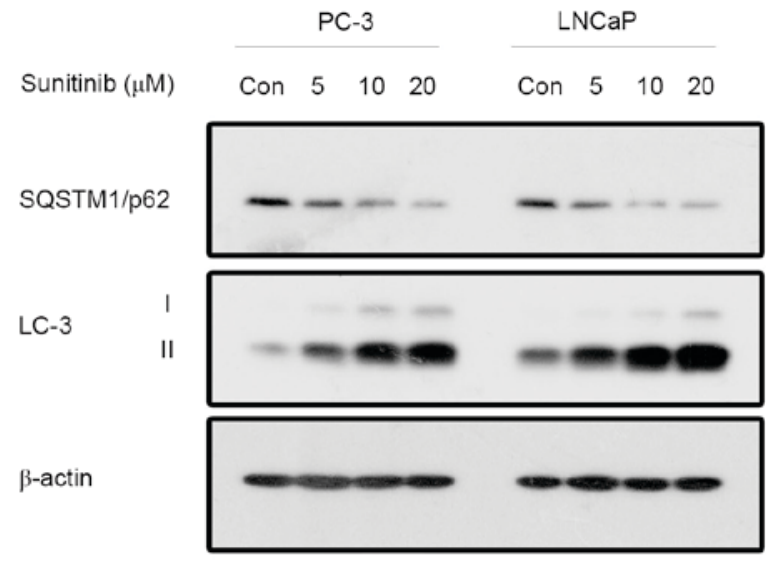

B

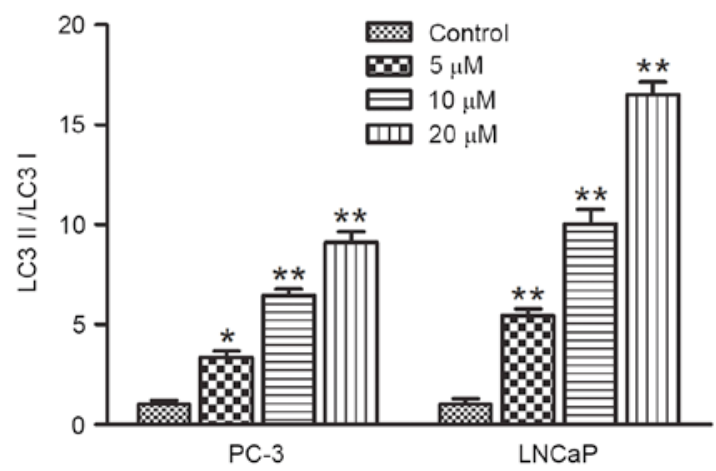

C

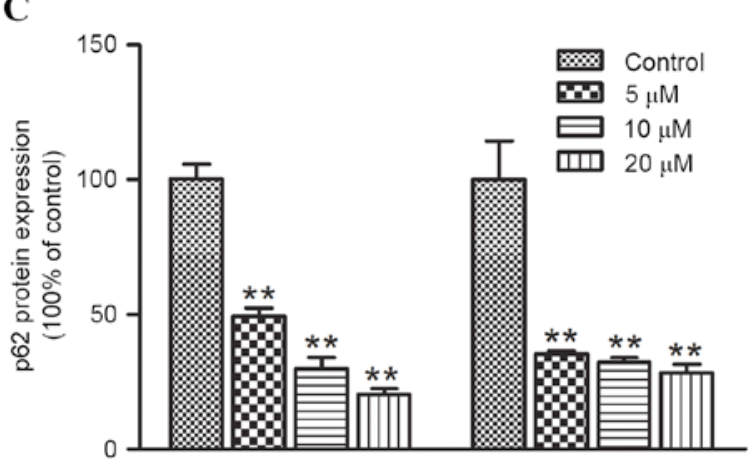

$\mathrm{PC}-3$

LNCaP

Figure 4. Western blotting analysis of sunitinib-induced autophagy in prostate cancer cells. (A) Following sunitinib treatment at different concentrations for $24 \mathrm{~h}$, increased levels of LC3-II protein expression and decreased levels of SQSTM1/p62 protein expression were observed in both PC-3 and LNCaP cells. (B) Fold changes of LC3-II/ LC3-I and (C) the expression level of SQSTM1/p62 between the treatment and the control groups were determined by three independent experiments and normalized by the total protein level. Data are presented as mean \pm standard error. ${ }^{*} \mathrm{P}<0.05$ and ${ }^{* *} \mathrm{P}<0.01$, vs. Con. LC3, microtubule associated protein 1A/1B-light chain 3; Con, control; SQSTM1/p62, sequestosome-1.

respectively) in both cell lines. Simultaneously, the phosphorylation of p70S6K was also inhibited (when comparing the 5, 10 or $20 \mu \mathrm{mol} / 1$ groups with the control, $\mathrm{P}=0.003,<0.001$ and $<0.001$ for $\mathrm{PC}-3$, and $\mathrm{P}=0.010,0.008$ and $<0.001$ for $\mathrm{LNCaP}$, respectively) (Fig. 5).

U0126 is a highly selective inhibitor of both MEK1 and MEK2, which are types of MAPK/ERK kinase (25). U0126 is able to block the ERK pathway (26); therefore, U0126 $(10 \mu \mathrm{M})$ was used to inhibit the phosphorylation of ERK1/2 in the present study. LC3II/I ratio was significantly increased when PC-3 and LNCaP cells were treated with $10 \mu \mathrm{M}$ sunitinib; however, a decrease in the LC3II/I ratio was observed when comparing the U1026+sunitinib group with the sunitinib group in PC-3 and LNCaP cells $(\mathrm{P}=0.008$ and $<0.001$, respectively). In addition, quantitation analysis revealed that when phosphorylation levels of ERK were inhibited, no significant increase of LC3II/I ratio was found after sunitinib treatment when compared with the control (Fig. 6). Overall, these results suggest that ERK1/2 and mTOR activation stimulates sunitinib-induced autophagy in PC-3 and LNCaP cells.

Autophagy and apoptosis have roles in sunitinib-mediated cell death in PC-3 and LNCaP cells. To investigate whether apoptosis or autophagy is involved in the growth inhibitory effect of sunitinib, 3-MA (5 $\mu \mathrm{M})$ was administered as a pre-treatment to inhibit sunitinib-induced autophagy and flow cytometry using Annexin V-PE and 7-AAD staining was performed, following $10 \mu \mathrm{M}$ sunitinib treatment for $48 \mathrm{~h}$ in both cell lines. Cleaved caspase-3 protein expression levels were also determined using western blot analysis.

Significant reductions in the number of viable cells (Annexin V-PE-/7-AAD') after treatment with sunitinib only (sunitinib groups) were observed in PC-3 and LNCaP cell lines when compared with controls $(\mathrm{P}=0.007$ and 0.038 , respectively), accompanied by significant increases of the number of apoptotic cells $(\mathrm{P}=0.001$ and 0.017 , respectively) (Annexin $\mathrm{V}-\mathrm{PE}^{+} / 7-\mathrm{AAD}^{-}$, early apoptosis; Annexin $\mathrm{V}-\mathrm{PE}^{+} /$7-AAD ${ }^{+}$, late apoptosis) (Fig. 7A and B). However, there was no significant difference observed between the 3-MA and control groups for apoptosis induction. However, when compared with sunitinib + 3-MA groups and 3-MA groups, combined sunitinib and 3-MA treatment resulted in significantly increased apoptotic cell death $(\mathrm{P}=0.003$ and 0.010 for PC-3 and $\mathrm{LNCaP}$ cells, respectively), with a higher percentage of $7-\mathrm{AAD}^{+}$cells. These results indicated that inhibition of autophagy by 3-MA enhanced sunitinib-induced apoptosis. Western blot analysis was carried out to detect the expression of cleaved caspase-3, a hallmark of apoptotic cell death which preceded the previously observed changes in nuclear morphology (27). Sunitinib groups or sunitinib + 3-MA groups exhibited increased expression levels of cleaved caspase-3 when compared with the control or 3-MA groups. Furthermore, inhibition of autophagy by 3-MA significantly enhanced the expression levels of cleaved caspase-3 induced 
A

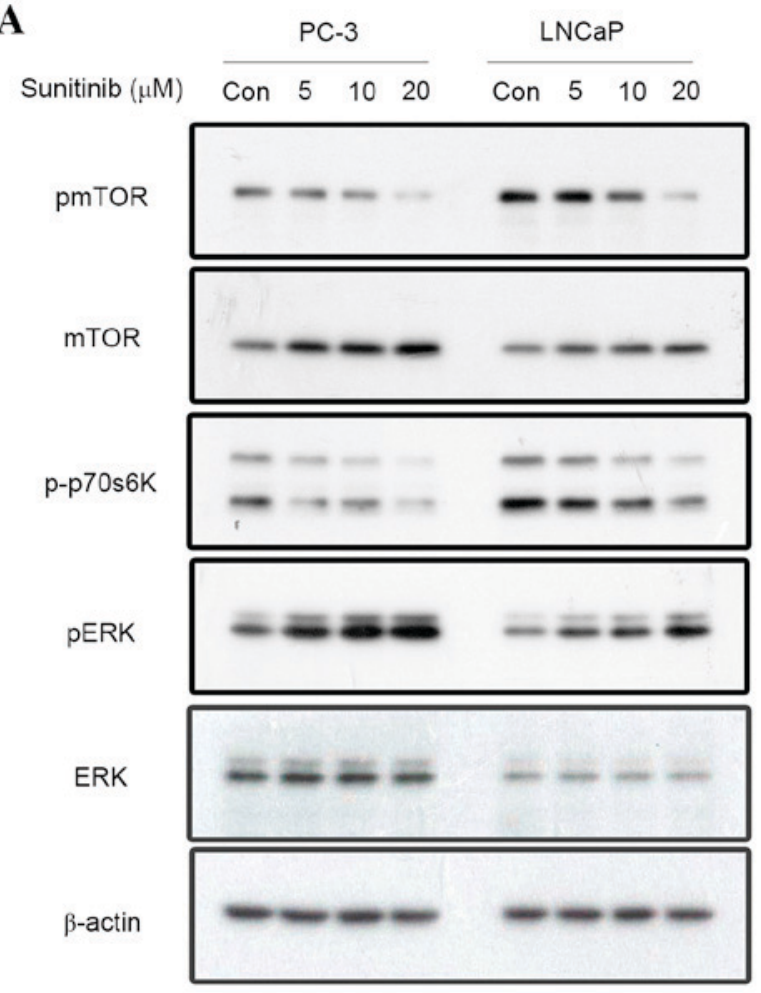

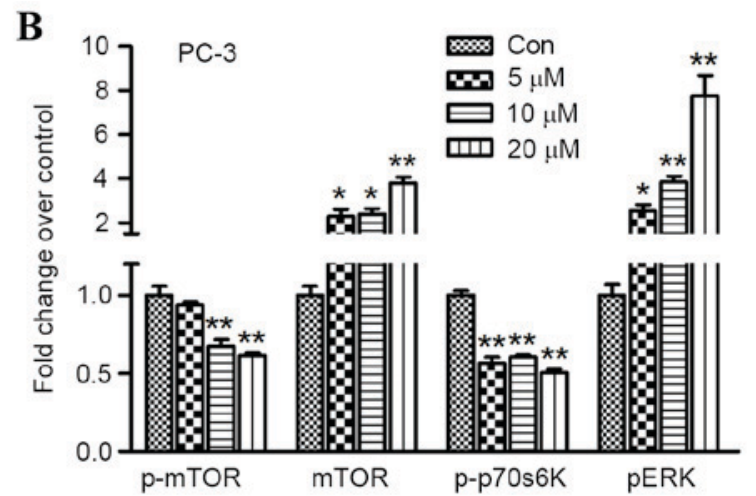

C

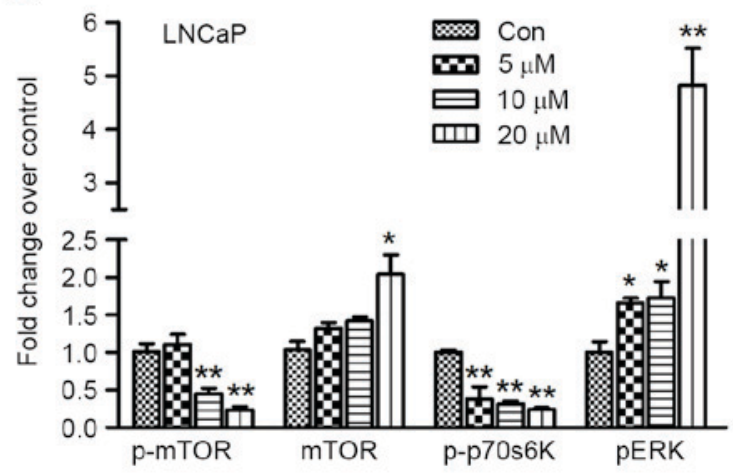

Figure 5. Effect of sunitinib on mTOR and ERK signaling in PC-3 and LNCaP cells. (A) Sunitinib treatment suppressed the phosphorylated levels of mTOR and p70S6K and activated the phosphorylated level of ERK1/2, as demonstrated by western blotting. Fold changes in p-mTOR, mTOR, p-p70S6K and p-ERK proteins in 5, 10, or $20 \mu \mathrm{M}$ sunitinib-treated groups and control groups in (B) PC-3 cells and (C) LNCaP cells. Results were determined by three independent experiments and normalized by the total protein level. Data are presented as mean \pm standard deviation. ${ }^{*} \mathrm{P}<0.05$ and ${ }^{* *} \mathrm{P}<0.01$, vs. Con. mTOR, mechanistic target of rapamycin; p70S6K, ribosomal protein S6 kinase beta-1; ERK 1/2, extracellular signal-regulated kinases 1/2; Con, control.

A

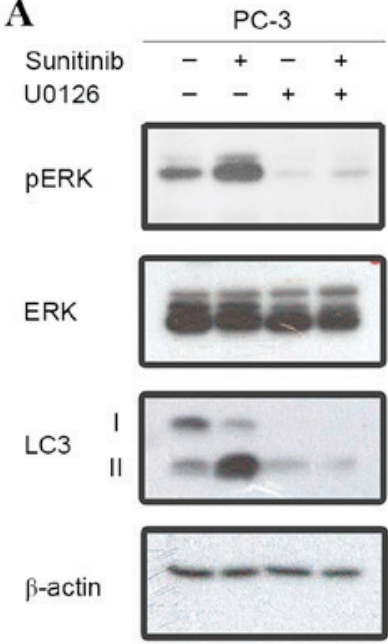

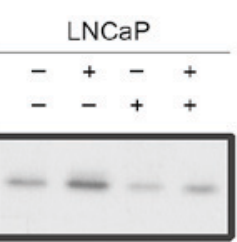
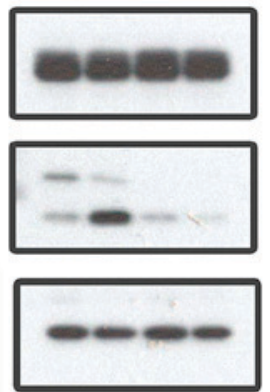

B

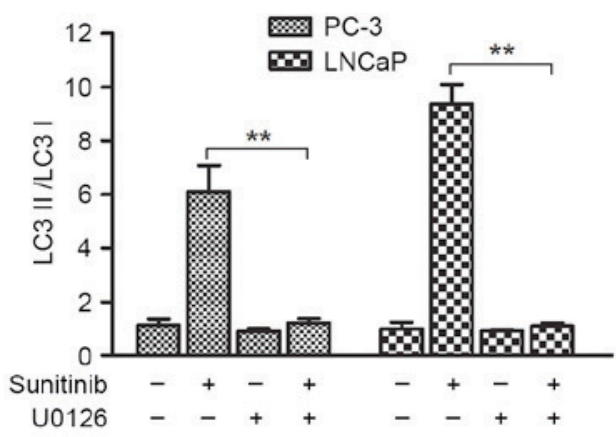

Figure 6. Inhibition of ERK1/2 by U1026 effects on the autophagy level induced by sunitinib. (A) Inhibition of the phosphorylation of ERK1/2 by U0126 (10 $\mu$ M) in PC-3 and LNCaP cells suppressed the increased fold changes of LC3II/I levels triggered by sunitinib, as demonstrated by using western blotting. (B) Fold changes of LC3II/I expression levels in sunitinib-treated groups and the control groups were determined by three independent experiments and normalized by the total protein level. Data are presented as mean \pm standard deviation, ${ }^{*} \mathrm{P}<0.05$ and ${ }^{* *} \mathrm{P}<0.01$, vs. control. ERK 1/2, extracellular signal-regulated kinases $1 / 2$; LC3, microtubule associated protein 1A/1B-light chain 3.

by sunitinib, when comparing the sunitinib groups with the sunitinib + 3-MA groups $(\mathrm{P}=0.019$ and 0.038 for $\mathrm{PC}-3$ and LNCaP, respectively) (Fig. 7C).

To further evaluate the interplay between apoptosis and autophagy and their effect on sunitinib cytotoxicity in $\mathrm{PCa}$ cells, a cell viability assay by MTT was performed. Following
$48 \mathrm{~h}$ of sunitinib treatment, inhibition of autophagy by $5 \mu \mathrm{M}$ 3-MA pre-treatment lead to a significant increase in the rate of cell viability when comparing the sunitinib group with the sunitinib + 3-MA group in PC-3 cells $(\mathrm{P}=0.40)$ (Fig. 8). A similar observation in the increased rate of cell viability was exhibited in LNCaP cells, although, no statistical significance 
A
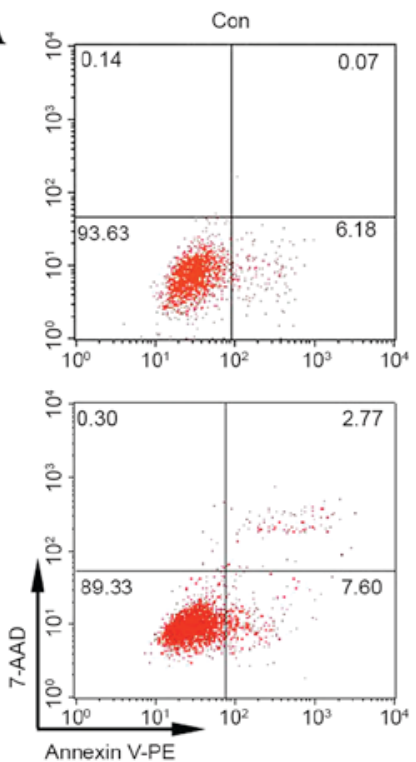

B

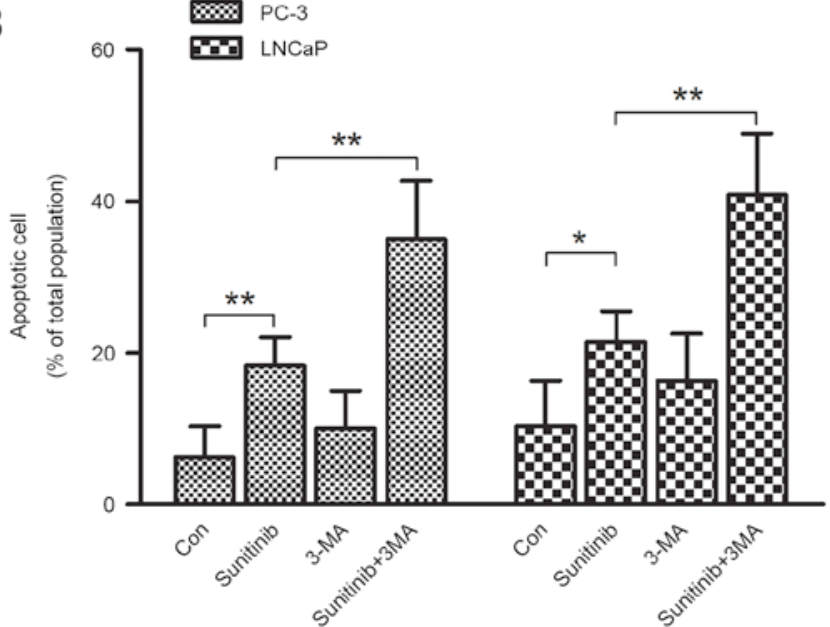

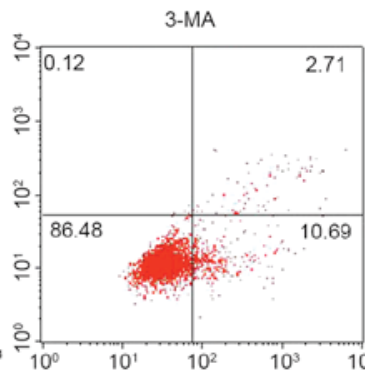
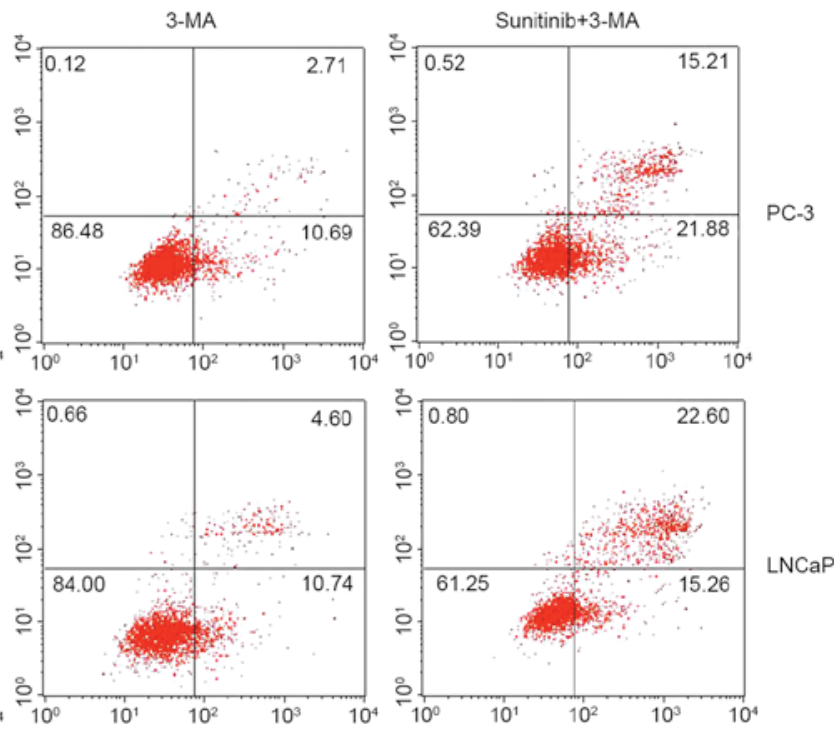

C

C
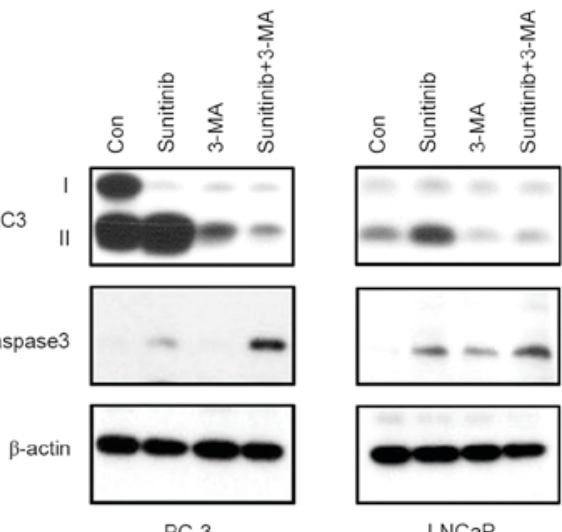

Cleaved caspase3
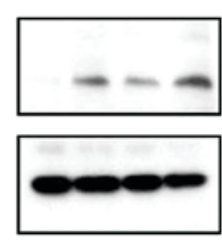

LNCaP

Figure 7. Inhibition of autophagy by 3-MA effects on sunitinib-induced cell apoptosis. (A) Flow cytometric analysis indicated inhibition of autophagy by 3-MA $(5 \mu \mathrm{M})$ increased the rate of apoptosis induced by sunitinib. (B) Percentage of apoptotic cells in control, sunitinib-treated, 3-MA-treated and sunitinib + 3-MA-treated groups in PC-3 and LNCaP cells (C) Following sunitinib treatment, caspase-3 was activated and inhibition of autophagy enhanced the activation of caspase-3. Data in panel (B) represent the mean \pm standard deviation of three independent experiments, ${ }^{*} \mathrm{P}<0.05$ and ${ }^{* *} \mathrm{P}<0.01$. 3-MA, 3-methyladenine; Con, control.

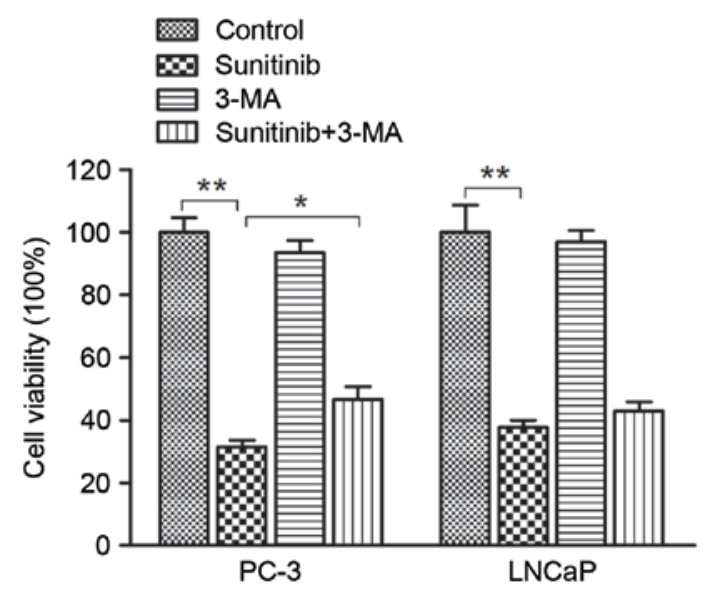

Figure 8 . Inhibition of autophagy by 3-MA effects on sunitinib-induced apoptosis. Sunitinib-induced cell death was reversed by inhibition of autophagy with 3-MA $(5 \mu \mathrm{M})$ in PC-3 cells, which was similarly observed in LNCaP cells; however, no statistical significance was detected in LNCaP cells. Data are presented as mean \pm standard deviation. ${ }^{*} \mathrm{P}<0.05$ and ${ }^{* *} \mathrm{P}<0.01$. 3-MA, 3-methyladenine. was indicated. In consideration of the flow cytometry assay results, we conclude that sunitinib-triggered cytotoxicity was mediated by autophagy and apoptotic cell death induction in PC-3 and LNCaP cells.

\section{Discussion}

Previous studies have advanced understanding of the role of vascular endothelial growth factor (VEGF), which has led to the addition of several agents to the therapeutic landscape for various tumor types. Among these antiangiogenic agents, sunitinib is a tyrosine kinase inhibitor that targets VEGF receptors 1, 2 and 3 and has been approved for the treatment of metastatic renal carcinoma (28) and gastro-intestinal stromal tumor (29).

In accordance with our results, several studies have observed a significant inhibitory and cytotoxicity effect on PCa cell lines via the regulation of hypoxia and angiogenesis $(18,30)$. These findings suggest a possible antitumor effect 
of sunitinib in PCa. However, there is a lack of studies on the antitumor effect and mechanism of action of sunitinib in PCa.

In the present study, sunitinib was revealed to inhibit the viability of PC-3 and LNCaP cells in a dose-dependent manner. Our findings are in accordance with the results of two previous studies, concerning anti-tumor and radiosensitivity of sunitinib on PC-3 and DU145 cells in vitro (31) and the preventative effects in the course from non-castration to castration of LNCaP xenograft prostate (19). In addition, cell cycle analysis in the present study revealed that, following $10 \mu \mathrm{M}$ of sunitinib treatment for $24 \mathrm{~h}$, the number of PC-3 and LNCaP cells in $\mathrm{S}$ and $\mathrm{G} 2 / \mathrm{M}$ phases was decreased, whereas the number of cells in G1 phase was increased, when compared with the controls. Similar results were reported when colonic stromal fibroblasts were treated with sunitinib mesylate (32). Moreover, Di Desidero et al (33) identified that sunitinib induced a concentration-dependent inhibition of the cyclin-D1 gene and protein expression, in HMVEC-d, 8305C and FB3 cells, respectively.

Autophagy is a highly conserved, homeostatic process by which intracellular constituents are delivered to lysosomes for degradation. It is activated in response to various environmental stresses that have been documented in human tumor cells, following treatment with chemotherapeutic drugs $(34,35)$. Furthermore, a previous study has indicated that excessive activation of autophagy may lead to another form of programmed cell death in a non-apoptotic manner (36). LC-3 is considered to be a strong marker of autophagy. Furthermore, the conversion of LC3-I to LC3-II and formation of LC3 puncta usually demonstrates the activation of autophagy (37). In addition, p62 degraded alongside autophagosomal contents, resulting in decreased p62 levels (38). In the present study, sunitinib treatment was revealed to promote autophagy in PC-3 and LNCaP cells in dose-dependent manner, as indicated by the increases in the LC3-II/LC3-I ratio and membrane-bound lapidated form of LC3, and the degradation of p62 protein observed. Ikeda et al (39) reported that sunitinib induced autophagy in rat pheochromocytoma PC12 cells and that this was dependent on the suppression of mTORC1 signaling and the formation of ULK1/2-Atg13-FIP200 complexes. In addition, another study discovered that sunitinib treatment for $24 \mathrm{~h}$ triggers incomplete autophagy, impaired cathepsin B activation and stimulated lysosomal-dependent necrosis in bladder cancer cells (40). To the best of our knowledge, the present study is the first to propose that autophagy in PCa cell lines may be stimulated by sunitinib.

mTOR and ERK1/2 are two major pathways that regulate autophagy induced by nutrient starvation. Cadmium (41) or TNF $\alpha$ treatment (42) have been clearly associated with ERK activation and autophagic programmed cell death; moreover, direct ERK activation by the overexpression of active MEK may promote autophagy without any other stimulus (43). The modifications exhibited by phosphorylated ERK (p-ERK) after sunitinib treatment are conflicting, according to previous reports $(44,45)$. Sunitinib treatment has been revealed to exhibit increased levels of p-ERK in bladder cancer cells (J82 and 5637) (40) and adrenocortical carcinoma (SW13) cells (46), whereas p-ERK levels were suppressed in human colonic stromal fibroblasts (32) and papillary thyroid cancer cells (44). The present study revealed that sunitinib significantly promoted
ERK1/2 phosphorylation and suppressed mTOR/p70S6K phosphorylation, which was consistent with the differences of LC3-II/LC3-I ratio and p62 expression observed. Furthermore, the highly selective MEK1/2 inhibitor, U0126, markedly reversed the induction of autophagy by sunitinib when compared with the sunitinib and U0126 combination group and the sunitinib group, which suggested that ERK signaling may have a role in sunitinib-induced autophagy. However, Diaz et al (31) reported that sunitinib promoted a decrease in the expression level of p-ERK in PC-3 cells after treatment. Considering that the maximum concentration of sunitinib used by Diaz et al (31) employed in that study was $5 \mu \mathrm{M}$, which is much lower than that of our study, both results may be reasonable and further research is required. It has been established that mTORC1 may suppress autophagy by promoting phosphorylation and inactivation of proteins involved in autophagosome formation $(47,48)$. The role of the mTOR substrate, p70S6Kinase 1 (S6K1), in autophagy remains controversial (49). However, one study has indicated that active S6K1 may decrease the level of LC3 processing and foci formation by autophagosomal vacuoles in cells treated with sulforaphane, and diminished levels of S6K1 or a lack of S6 kinases resulted in the accumulation of autophagosomes in PC-3 cells (50). This is consistent with the variation trend of p-mTOR and p-p70S6K demonstrated in the present study, which suggested that mTOR signaling is also involved in the regulation of sunitinib-induced autophagy. Overall, the present data revealed that sunitinib may promote autophagy in $\mathrm{PCa}$ cells through the activation of ERK1/2 and the inhibition of mTOR.

Autophagy, which is described as a 'double-edged sword', has a key role in tumorigenesis, progression and oncotherapy. On the one hand, autophagy manifests as a survival pathway that allows tumor cells to live through various severe environments (51); whereas, autophagy has also been revealed to contribute to cell death, which was previously confirmed in cancer cells undergoing antineoplastic therapy (52). To establish the role of autophagy in sunitinib-induced cell death, 3-MA $(5 \mu \mathrm{M})$ was used as a pre-treatment to block autophagy and subsequent flow cytometry and cell proliferation assays were employed to determine apoptosis and cell viability. These analyses revealed that sunitinib treatment induced an increase in the rate of cellular apoptosis, while inhibition of autophagy by 3-MA led to a remarkable enhancement in sunitinib-induced apoptosis. Furthermore, the expression of cleaved caspase-3 protein, a cysteine protease involved in the 'execution' phase of cellular apoptosis and a key regulator of tumor repopulation promoting generated from the dying cells (53), was detected by western blotting. Western blot analysis showed a similar changing trend in accordance with the change of apoptosis rate: Sunitinib only treatment induced significant increases in the number of apoptotic cells, while a further enhancement of the apoptotic rate was detected after the inhibition of autophagy by 3-MA when compared sunitinib + 3-MA group with sunitinib group. Coincidentally, inhibition of autophagy by 3-MA significantly enhanced the expression levels of cleaved caspase-3 induced by sunitinib, when comparing sunitinib groups with sunitinib + 3-MA groups. These findings suggest that, besides promoting autophagy, sunitinib may also generate apoptosis in a caspase-3-dependent manner in 
PC-3 and LNCaP cells. Additionally, 3-MA (5 $\mu \mathrm{M})$ was used to inhibit autophagy and cell viability following $48 \mathrm{~h}$ of $10 \mu \mathrm{M}$ sunitinib treatment was determined by MTT. Unexpectedly, the cell death rate of PC-3 cells significantly decreased when treated with sunitinib and 3-MA pre-treatment; despite this, the inhibition of autophagy lead to a significant enhancement of sunitinib-induced apoptosis. Similar observations were identified in LNCaP cells; however, no statistical significance was detected. Collectively, these findings indicated that apoptosis and autophagic cell death have key roles in sunitinib-induced cytotoxicity in PCa cells. While relatively few reports focus on the induction of autophagy by sunitinib $(39,40)$, the present results suggest that autophagy may be an important component in the cytotoxicity resulting from sunitinib treatment in PCa cells.

Phase II trials of single-agent sunitinib in metastatic castration-resistant PCa (mCRPC) have suggested that the antitumor activity, which was assessed by a $>50 \%$ decline in prostate-specific antigen levels and tumor shrinkage, exhibited an acceptable safety profile $(18,30)$. In addition, several drugs with anti-angiogenic properties have proceeded to Phase III evaluation for the treatment of patients with CRPC; however, no phase III study to date has succeeded in demonstrating a survival benefit in large randomized studies (54), which indicates that further advances are required.

In conclusion, the present study demonstrated that sunitinib manifested an antineoplastic effect on PCa cell lines in vitro. Sunitinib was revealed to stimulate autophagy in PCa cells via the regulation of ERK1/2 phosphorylation and mTOR signaling. Autophagic and apoptotic cell death were demonstrated to have roles in the cytotoxic effects induced by sunitinib in PCa cells. Further studies are required to fully investigate the interactions and signal pathways involved in the conversion between autophagic and apoptotic cell death. In addition, the findings of the present study suggest that implementing autophagy combined sunitinib treatment may be beneficial in devising novel anti-cancer strategies in PCa.

\section{Acknowledgements}

This study was partly supported by the China National Natural Science Foundation (grant no. 81172421), Ministry of Science and Technology of China (grant no. 2013CB835300), Natural Science Foundation of Guangdong Province (grant no. S2012010010009) and Science and Technology Project of Guangdong Province (grant no. 2011B031800199).

\section{References}

1. Cuzick J, Thorat MA, Andriole G, Brawley OW, Brown PH, Culig Z, Eeles RA, Ford LG, Hamdy FC, Holmberg L, et al: Prevention and early detection of prostate cancer. Lancet Oncol 15: e484-e492, 2014.

2. Gilligan T and Kantoff PW: Chemotherapy for prostate cancer. Urology 60 (3 Suppl 1): S94-S100, 2002.

3. Thakur MK and Vaishampayan U: Multifaceted and personalized therapy of advanced prostate cancer. Curr Opin Oncol 28: 222-231, 2016.

4. Lum JJ, Bauer DE, Kong M, Harris MH, Li C, Lindsten T and Thompson CB: Growth factor regulation of autophagy and cell survival in the absence of apoptosis. Cell 120: 237-248, 2005.

5. Tanida I: Autophagosome formation and molecular mechanism of autophagy. Antioxid Redox Signal 14: 2201-2214, 2011.
6. Klionsky DJ, Abdalla FC, Abeliovich H, Abraham RT, AcevedoArozena A, Adeli K, Agholme L, Agnello M, Agostinis P, Aguirre-Ghiso JA, et al: Guidelines for the use and interpretation of assays for monitoring autophagy. Autophagy 8: 445-544, 2012.

7. Bursch W: The autophagosomal-lysosomal compartment in programmed cell death. Cell Death Differ 8: 569-581, 2001.

8. Mihaylova MM and Shaw RJ: The AMPK signalling pathway coordinates cell growth, autophagy and metabolism. Nat Cell Biol 13: 1016-1023, 2011.

9. Pyo JO, Nah J and Jung YK: Molecules and their functions in autophagy. Exp Mol Med 44: 73-80, 2012.

10. Cagnol S and Chambard JC: ERK and cell death: Mechanisms of ERK-induced cell death-apoptosis, autophagy and senescence. FEBS J 277: 2-21, 2010.

11. Coppin C, Kollmannsberger C, Le L, Porzsolt F and Wilt TJ: Targeted therapy for advanced renal cell cancer (RCC): A Cochrane systematic review of published randomised trials. BJU Int 108: 1556-1563, 2011.

12. Gori S, Foglietta J, Rossi M, Hamzaj A, Stocchi L, Galuppo C, Picece V, Puxeddu E and Furlani L: Sunitinib therapy in metastatic papillary thyroid cancer. Tumori 99: 285e-287e, 2013.

13. O'Reilly EM, Niedzwiecki D, Hall M, Hollis D, Bekaii-Saab T, Pluard T, Douglas K, Abou-Alfa GK, Kindler HL, Schilsky RL, et al: A cancer and leukemia group B phase II study of sunitinib malate in patients with previously treated metastatic pancreatic adenocarcinoma (CALGB 80603). Oncologist 15: 1310-1319, 2010.

14. Reni M, Cereda S, Milella M, Novarino A, Passardi A, Mambrini A, Di Lucca G, Aprile G, Belli C, Danova M, et al: Maintenance sunitinib or observation in metastatic pancreatic adenocarcinoma: A phase II randomised trial. Eur J Cancer 49: 3609-3615, 2013.

15. Uno F, Fujiwara Y and Fujiwara T: A long-term control of gastrointestinal stromal tumor with sunitinib. Gan To Kagaku Ryoho 40: 1241-1244, 2013.

16. Broxterman HJ, Gotink KJ and Verheul HM: Understanding the causes of multidrug resistance in cancer: A comparison of doxorubicin and sunitinib. Drug Resist Updat 12: 114-126, 2009.

17. Fuereder T, Jaeger-Lansky A, Hoeflmayer D, Preusser M, Strommer S, Cejka D, Koehrer S, Crevenna R and Wacheck V: mTOR inhibition by everolimus counteracts VEGF induction by sunitinib and improves anti-tumor activity against gastric cancer in vivo. Cancer Lett 296: 249-256, 2010.

18. Dror Michaelson M, Regan MM, Oh WK, Kaufman DS Olivier K, Michaelson SZ, Spicer B, Gurski C, Kantoff PW and Smith MR: Phase II study of sunitinib in men with advanced prostate cancer. Ann Oncol 20: 913-920, 2009.

19. Jing C, Ning J and Yuanjie N: The preventative effects of sunitinib malate observed in the course from non-castration to castration LNCaP xenograft prostate tumors. J Cancer Res Clin Oncol 138: 2137-2143, 2012.

20. Carlisle B, Demko N, Freeman G, Hakala A, MacKinnon N, Ramsay T, Hey S, London AJ and Kimmelman J: Benefit, Risk, and outcomes in drug development: A systematic review of sunitinib. J Natl Cancer Inst 108: djv292, 2015.

21. Basch E, Loblaw DA, Oliver TK, Carducci M, Chen RC, Frame JN, Garrels K, Hotte S, Kattan MW, Raghavan D, et al: Systemic therapy in men with metastatic castration-resistant prostate cancer: American society of clinical oncology and cancer care ontario clinical practice guideline. J Clin Oncol 32: 3436-3448, 2014.

22. Deretic V and Levine B: Autophagy, immunity, and microbial adaptations. Cell Host Microbe 5: 527-549, 2009.

23. Chen S, Rehman SK, Zhang W, Wen A, Yao L and Zhang J: Autophagy is a therapeutic target in anticancer drug resistance. Biochim Biophys Acta 1806: 220-229, 2010.

24. Jin $S$ and White E: Role of autophagy in cancer: Management of metabolic stress. Autophagy 3: 28-31, 2007.

25. Favata MF, Horiuchi KY, Manos EJ, Daulerio AJ, Stradley DA, Feeser WS, Van Dyk DE, Pitts WJ, Earl RA, Hobbs F, et al: Identification of a novel inhibitor of mitogen-activated protein kinase kinase. J Biol Chem 273: 18623-18632, 1998.

26. Fukazawa H, Noguchi K, Murakami Y and Uehara Y: Mitogen-activated protein/extracellular signal-regulated kinase kinase (MEK) inhibitors restore anoikis sensitivity in human breast cancer cell lines with a constitutively activated extracellular-regulated kinase (ERK) pathway. Mol Cancer Ther 1: 303-309, 2002. 
27. Johnson VL, Ko SC, Holmstrom TH, Eriksson JE and Chow SC: Effector caspases are dispensable for the early nuclear morphological changes during chemical-induced apoptosis. J Cell Sci 113: 2941-2953, 2000 .

28. Motzer RJ, Hutson TE, Tomczak P, Michaelson MD, Bukowski RM, Rixe O, Oudard S, Negrier S, Szczylik C, Kim ST, et al: Sunitinib versus interferon alfa in metastatic renal-cell carcinoma. N Engl J Med 356: 115-124, 2007.

29. Demetri GD, van Oosterom AT, Garrett CR, Blackstein ME, Shah MH, Verweij J, McArthur G, Judson IR, Heinrich MC, Morgan JA, et al: Efficacy and safety of sunitinib in patients with advanced gastrointestinal stromal tumour after failure of imatinib: A randomised controlled trial. Lancet 368: 1329-1338, 2006.

30. Sonpavde G, Periman PO, Bernold D, Weckstein D, Fleming MT, Galsky MD, Berry WR, Zhan F, Boehm KA, Asmar L and Hutson TE: Sunitinib malate for metastatic castration-resistant prostate cancer following docetaxel-based chemotherapy. Ann Oncol 21: 319-324, 2010.

31. Diaz R, Nguewa PA, Redrado M, Manrique I and Calvo A: Sunitinib reduces tumor hypoxia and angiogenesis, and radiosensitizes prostate cancer stem-like cells. Prostate 75: 1137-1149, 2015.

32. Wang ZH, Li Q, Ruan SQ, Xiao Q, Liu Y, Hu YT, Hu LF, Chen HY, Zheng S, Zhang SZ and Ding KF: Sunitinib mesylate inhibits proliferation of human colonic stromal fibroblasts in vitro and in vivo. J Zhejiang Univ Sci B 15: 701-712, 2014

33. Di Desidero T, Fioravanti A, Orlandi P, Canu B, Giannini R, Borrelli N, Man S, Xu P, Fontanini G, Basolo F, et al: Antiproliferative and proapoptotic activity of sunitinib on endothelial and anaplastic thyroid cancer cells via inhibition of Akt and ERK1/2 phosphorylation and by down-regulation of cyclin-D1. J Clin Endocrinol Metab 98: E1465-E1473, 2013.

34. Shimizu S, Kanaseki T, Mizushima N, Mizuta T, Arakawa-Kobayashi S, Thompson CB and Tsujimoto Y: Role of Bcl-2 family proteins in a non-apoptotic programmed cell death dependent on autophagy genes. Nat Cell Biol 6: 1221-1228, 2004

35. Bolt AM,Zhao F, Pacheco S and Klimecki WT: Arsenite-induced autophagy is associated with proteotoxicity in human lymphoblastoid cells. Toxicol Appl Pharmacol 264: 255-261, 2012.

36. Levine B and Klionsky DJ: Development by self-digestion: Molecular mechanisms and biological functions of autophagy. Dev Cell 6: 463-477, 2004.

37. Kabeya Y, Mizushima N, Ueno T, Yamamoto A, Kirisako T, Noda T, Kominami E, Ohsumi Y and Yoshimori T: LC3, a mammalian homologue of yeast Apg8p, is localized in autophagosome membranes after processing. EMBO J 19: 5720-5728, 2000.

38. Klionsky DJ: Coming soon to a journal near you-the updated guidelines for the use and interpretation of assays for monitoring autophagy. Autophagy 10: 1691, 2014.

39. Ikeda T, Ishii KA, Saito Y, Miura M, Otagiri A, Kawakami Y, Shimano H, Hara H and Takekoshi K: Inhibition of autophagy enhances sunitinib-induced cytotoxicity in rat pheochromocytoma PC12 cells. J Pharmacol Sci 121: 67-73, 2013.

40. Santoni M, Amantini C, Morelli MB, Liberati S, Farfariello V, Nabissi M, Bonfili L, Eleuteri AM, Mozzicafreddo M, Burattini L, et al: Pazopanib and sunitinib trigger autophagic and non-autophagic death of bladder tumour cells. Br J Cancer 109: 1040-1050, 2013.
41. Wang SH, Shih YL, Ko WC, Wei YH and Shih CM: Cadmium-induced autophagy and apoptosis are mediated by a calcium signaling pathway. Cell Mol Life Sci 65: 3640-3652, 2008.

42. Sivaprasad U and Basu A: Inhibition of ERK attenuates autophagy and potentiates tumour necrosis factor-alpha-induced cell death in MCF-7 cells. J Cell Mol Med 12: 1265-1271, 2008.

43. Corcelle E, Nebout M, Bekri S, Gauthier N, Hofman P, Poujeol P, Fénichel P and Mograbi B: Disruption of autophagy at the maturation step by the carcinogen lindane is associated with the sustained mitogen-activated protein kinase/extracellular signal-regulated kinase activity. Cancer Res 66: 6861-6870, 2006.

44. Fenton MS, Marion KM, Salem AK, Hogen R, Naeim F and Hershman JM: Sunitinib inhibits MEK/ERK and SAPK/JNK pathways and increases sodium/iodide symporter expression in papillary thyroid cancer. Thyroid 20: 965-974, 2010.

45. Voce P, D'Ágostino M, Moretti S, Sponziello M, Rhoden K, Calcinaro F, Tamburrano G, Tallini G, Puxeddu E, Filetti S, et al: Sunitinib inhibits tumor vascularity and growth but does not affect Akt and ERK phosphorylation in xenograft tumors. Oncol Rep 26: 1075-1080, 2011.

46. Lin CI, Whang EE, Moalem J and Ruan DT: Strategic combination therapy overcomes tyrosine kinase coactivation in adrenocortical carcinoma. Surgery 152: 1045-1050, 2012.

47. Jung CH, Jun CB, Ro SH, Kim YM, Otto NM, Cao J, Kundu M and Kim DH: ULK-Atg13-FIP200 complexes mediate mTOR signaling to the autophagy machinery. Mol Biol Cell 20: 1992-2003, 2009.

48. Nazio F, Strappazzon F, Antonioli M, Bielli P, Cianfanelli V, Bordi M, Gretzmeier C, Dengjel J, Piacentini M, Fimia GM and Cecconi F: mTOR inhibits autophagy by controlling ULK1 ubiquitylation, self-association and function through AMBRA1 and TRAF6. Nat Cell Biol 15: 406-416, 2013.

49. Hosokawa N, Hara T, Kaizuka T, Kishi C, Takamura A, Miura Y, Iemura S, Natsume T, Takehana K, Yamada N, et al: Nutrient-dependent mTORC1 association with the ULK1-Atg13-FIP200 complex required for autophagy. Mol Biol Cell 20: 1981-1991, 2009.

50. Hac A, Domachowska A, Narajczyk M, Cyske K, Pawlik A and Herman-Antosiewicz A: S6K1 controls autophagosome maturation in autophagy induced by sulforaphane or serum deprivation. Eur J Cell Biol 94: 470-481, 2015.

51. Yan L, Vatner DE, Kim SJ, Ge H, Masurekar M, Massover WH, Yang G, Matsui Y, Sadoshima J and Vatner SF: Autophagy in chronically ischemic myocardium. Proc Natl Acad Sci USA 102: 13807-13812, 2005.

52. Notte A, Leclere L and Michiels C: Autophagy as a mediator of chemotherapy-induced cell death in cancer. Biochem Pharmacol 82: 427-434, 2011.

53. Donato AL, Huang Q, Liu X, Li F, Zimmerman MA and Li CY: Caspase 3 promotes surviving melanoma tumor cell growth after cytotoxic therapy. J Invest Dermatol 134: 1686-1692, 2014.

54. Beltran H, Kaur G, de España CG and Tagawa ST: Exploring the role of anti-angiogenic therapies in prostate cancer: Results from the phase 3 trial of sunitinib. Asian J Androl 16: 568-569, 2014. 